"Peculiarities of the Ukrainian housing and utility services enterprises activity in the context of defining their development potential"

\begin{tabular}{|c|c|c|}
\hline AUTHORS & \multicolumn{2}{|c|}{$\begin{array}{l}\text { Nataliia Pedchenko (D https://orcid.org/0000-0001-5093-2453 } \\
\text { Mariya Kimurzhiy }\end{array}$} \\
\hline ARTICLE INFO & \multicolumn{2}{|c|}{$\begin{array}{l}\text { Nataliia Pedchenko and Mariya Kimurzhiy (2018). Peculiarities of the Ukrainian } \\
\text { housing and utility services enterprises activity in the context of defining their } \\
\text { development potential. Public and Municipal Finance, } 7(1), 32-40 \text {. } \\
\text { doi:10.21511/pmf.07(1).2018.04 }\end{array}$} \\
\hline DOI & \multicolumn{2}{|c|}{ http://dx.doi.org/10.21511/pmf.07(1).2018.04 } \\
\hline RELEASED ON & \multicolumn{2}{|l|}{ Wednesday, 27 June 2018} \\
\hline RECEIVED ON & \multicolumn{2}{|l|}{ Friday, 18 May 2018} \\
\hline ACCEPTED ON & \multicolumn{2}{|l|}{ Wednesday, 13 June 2018} \\
\hline LICENSE & \multicolumn{2}{|c|}{$\begin{array}{l}\text { This work is licensed under a Creative Commons Attribution } 4.0 \text { International } \\
\text { License }\end{array}$} \\
\hline JOURNAL & \multicolumn{2}{|l|}{ "Public and Municipal Finance" } \\
\hline ISSN PRINT & \multicolumn{2}{|l|}{ 2222-1867 } \\
\hline ISSN ONLINE & \multicolumn{2}{|l|}{ 2222-1875 } \\
\hline PUBLISHER & \multicolumn{2}{|c|}{ LLC "Consulting Publishing Company "Business Perspectives" } \\
\hline FOUNDER & \multicolumn{2}{|c|}{ LLC "Consulting Publishing Company "Business Perspectives" } \\
\hline$\sigma^{\circ}$ & $D$ & ニニこ \\
\hline NUMBER OF REFERENCES & NUMBER OF FIGURES & NUMBER OF TABLES \\
\hline 20 & 3 & 4 \\
\hline
\end{tabular}

(c) The author(s) 2022. This publication is an open access article. 
Nataliia Pedchenko (Ukraine), Mariya Kimurzhiy (Ukraine)

\title{
Peculiarities of the Ukrainian housing and utility services enterprises activity in the context of defining their development potential
}

\begin{abstract}
The aim of the article is to study the peculiarities of housing and utility services enterprises activity as factors of influence on their development potential.

Research methodology. When solving the tasks given in the article, method of hypotheses and statistical research, methods for analyzing socio-economic factors of influence on enterprises' development potential are used.

Results. The authors proved the fairness of the presented scientific hypotheses as for peculiarities of housing and utility services enterprises in Ukraine, specifically, existence of natural monopoly of housing and utility services enterprises; limitations of the enterprise management functions in the sphere of setting up prices and standards for services; necessity to ensure long-term activities and continuity of production; non-compliance of quality, nomenclature of services, their reliability, economic feasibility of the tariffs, social and environmental labor security with the requirements of European standards for country's development; presence of the significant accounts receivable, which is caused by time lag between the consumers' use of services and resources provided and paying for them; dependence of results of enterprises financial activity on the current political and economic situation in the country.

Practical implications of the research results. Taking into account the proved hypotheses, vector directions of housing and utility services enterprises development potential were shaped in the article.
\end{abstract}

Keywords: development potential, housing and utility services enterprises potential, method of hypotheses, housing and utility services sector development.

JEL Classification: D22.

Received on: $18^{\text {th }}$ of May, 2018.

Accepted on: $13^{\text {th }}$ of June, 2018.

\section{Introduction}

The development of the national housing and utility services enterprises is a source of ensuring the tasks of socio-economic nature, self-reliance and competitiveness of the national economy in general. The sphere of housing and utility services is important and at the same time very specific, which is explained, on the one hand, by large-scale use of the services and social focus of the activity and on the other hand, critically dangerous state of the majority of housing and utility services enterprises, worn-out state of main means, significant accounts receivable, limitations in regulating prices and tariffs.

\section{Literature review}

Housing and utility services are one of the most necessary benefits for people, which ensures their existence and quality of their life (Dymchenko, 2009). According to the Law of Ukraine "On housing and utility services", housing and utility services are the results of business activities aimed at ensuring the living conditions and/or the people living in residential

(C) Limited Liability Company "Consulting Publishing Company "Business Perspectives", 2018.

Nataliia Pedchenko, Doctor of Economics, Professor, First Vice-rector of Poltava University of Economics and Trade, Ukraine.

Mariya Kimurzhiy, Deputy Director on work and work-study, BilhorodDnistrovskyi College of Economics and Law of Poltava University of Economics and Trade, Ukraine. or non-residential premises, houses and buildings, complexes of houses and buildings according to norms, standards, procedures and rules, which is performed based on corresponding agreements for housing and utility services (Law of Ukraine, 2017). Ensuring the housing and utility services enterprises activities is important for health and welfare of people, and the enterprises in this sphere play a central role not only in ensuring people's health, but also in contributing to conglomeration of people, prosperity without harm to the state and the environment (Takala Annina, 2017). Housing and utility services enterprises perform the function of territory's sustenance, their activity to a large extent forms the area of human life comfortable life in the city, township, village. They are the ones which are at the turning point of the problems of evolution of the crisis, on the one hand, and formation of the social protection systems, on the other hand (Brazhnikova, 2010). That's why Apostoliuk noted that the principle of increasing the profitability for housing and utility services enterprises should not be the main result of their activity, as operation of this sector realizes rather social function than economic one (Apostoliuk, 2014).

When studying the housing and utility services sector as socio-economic system, Baldzhy notes its advantages and disadvantages (the former are systemic support of population, complexity in services provision, possibility of attracting the investments; the 
latter are time dimension, significant capital-output ratio, insufficient legislative framework (Baldzhy, 2017). Poliakova states that the level of this sector development does not fully meet the needs of the population, material and technical base of the enterprises and organizations of the sector requires expansion and improvement (Poliakova, 2012). Lukianov fairly states that the absence of systemic, targeted, effective state and regional policy of this sector formation and chronic lack of financial resources caused deep crisis of housing and utility services enterprises and, as a result, critical state of housing utilities, inability to provide the population with housing and utility services to the necessary extent and of the adequate quality (Lukianov, 2014). Ukrainian (Dymchenko, 2009; Baldzhy, 2017; Lukianov, 2014; Peresada, 2014) and foreign scientists (Palme, 2010; Robinson \& Cole, 2015; Takala, 2017) emphasize the problems of formation of the housing and utility services enterprises development strategy and increasing its potential. Herewith, Peresada highlights that ignoring the peculiarities of housing and utility services sector, specifics of sectoral production does not allow to develop clear strategy of housing and utility services enterprises development (Peresada, 2014). Therefore, the primary preparatory stage is defining the peculiarities of housing and utility services enterprises activity, which will become the basis for developing clear recommendations for increasing the housing and utility services enterprises development potential.

\section{Methods}

To study the peculiarities of housing and utility services enterprises activity, method of hypotheses was used, which lies in the development of scientific hypothesis based on studying different characteristics of the essence of the researched phenomenon via different means of understanding and provides for formulating the hypothesis, building the calculation scheme-algorithm (model), its study, analysis, development of theoretical provisions. The metaanalysis was performed and a series of hypotheses were defined, which need to be proved (Figure 1).

Aim: to define the peculiarities of housing and utility services enterprises activity

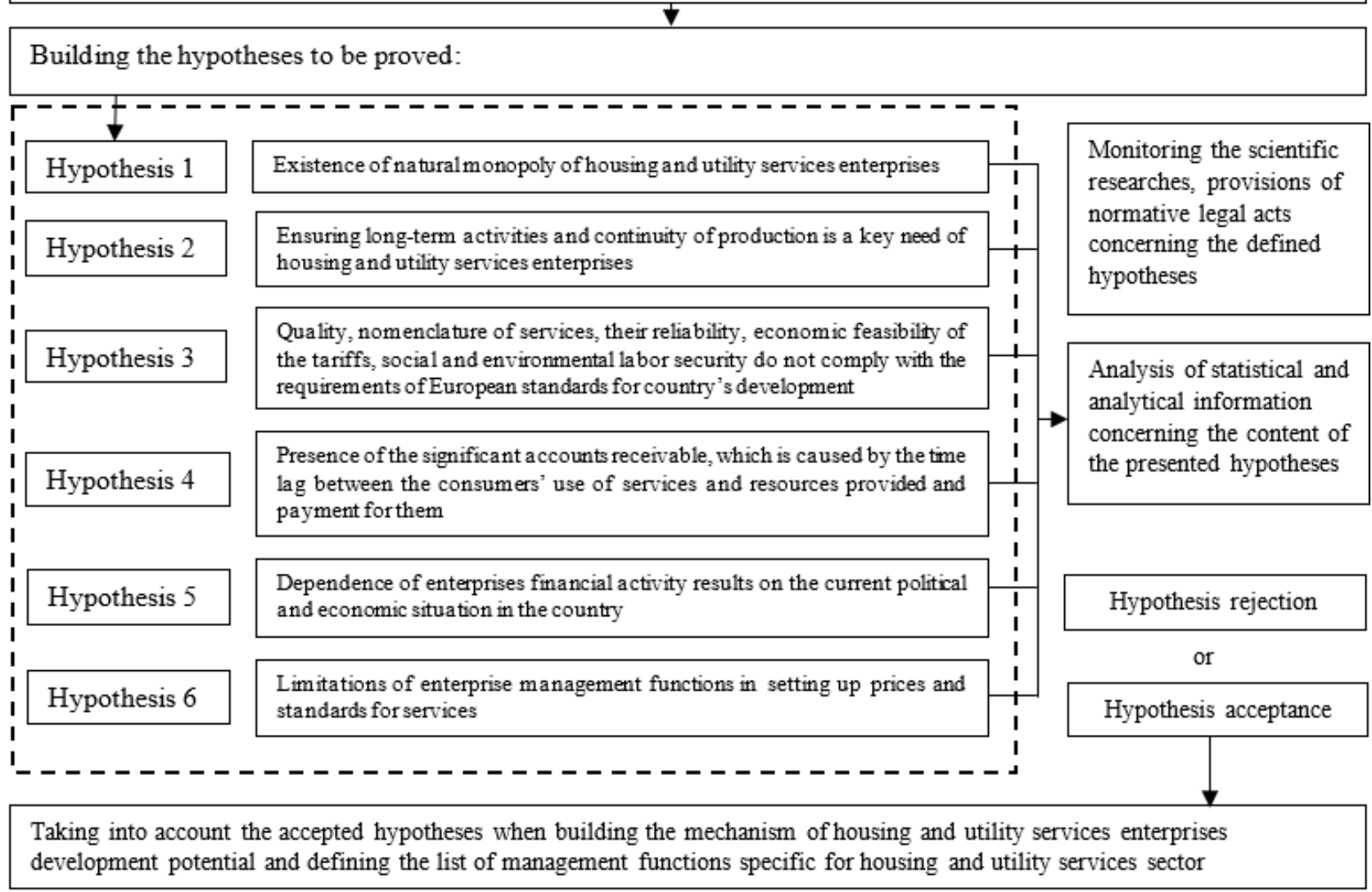

Figure 1. Algorithm of defining the peculiarities of housing and utility services enterprises activity based on method of hypotheses

\section{Research findings}

Hypothesis 1: Existence of natural monopoly of housing and utility services enterprises (due to the state owning the natural resources of Ukraine).
The peculiarities of housing and utility services market are connected with the nature of services as a commodity, which in their majority belong to the state based on ownership rights. According to the Law of Ukraine "On Natural Monopolies" (Law of Ukraine, 
2017), the enterprises occupying a monopolistic position on the market include the energy production and distribution enterprises, central water supply and sewerage enterprises, central heat energy supply and transportation enterprises, natural gas transportation enterprises and, correspondingly, tariffs for their services are established by the state bodies of Ukraine. Besides, the monopolized services include: central water supply, water discharge, gas supply, electricity supply, heating. At the same time, in the spheres of housing and utility services sector such as maintaining the common property of highrise residential houses, current repair of multi-unit residential houses common property, waste management can be the object of purchase and sale at the competitive markets (the structure of the housing and utility services market is given in Table 1).

Table 1. Increase in the number of Ukrainian housing and utility services enterprises according to the types of services in the period 2014-2016

\begin{tabular}{|c|c|c|c|c|c|}
\hline \multirow[b]{2}{*}{ Name } & \multirow{2}{*}{$\begin{array}{c}2014 \\
\text { Number of } \\
\text { enterprises, units }\end{array}$} & \multirow{2}{*}{$\begin{array}{c}2015 \\
\text { Number of } \\
\text { enterprises, units }\end{array}$} & \multirow{2}{*}{$\begin{array}{c}2016 \\
\text { Number of } \\
\text { enterprises, units }\end{array}$} & \multicolumn{2}{|c|}{ Change in number of enterprises } \\
\hline & & & & $\begin{array}{c}\text { in } 2015 \text { compared } \\
\text { to } 2014\end{array}$ & $\begin{array}{c}\text { in } 2016 \text { compared } \\
\text { to } 2015\end{array}$ \\
\hline \multicolumn{6}{|c|}{ Ukraine } \\
\hline \multicolumn{6}{|c|}{ Monopolized services } \\
\hline Electricity distribution & 156 & 153 & 135 & -3 & -18 \\
\hline Sale of electricity & 78 & 92 & 85 & 14 & -7 \\
\hline Gas production & 5 & 7 & 7 & 2 & 0 \\
\hline Distribution of gaseous fuels through local pipelines & 83 & 75 & 90 & -8 & 15 \\
\hline Sale of gas through local pipelines & 115 & 151 & 155 & 36 & 4 \\
\hline Supply of steam, hot water and conditioned air & 605 & 711 & 748 & 106 & 37 \\
\hline Water sampling, cleaning and supply & 1,561 & 1,577 & 1,583 & 16 & 6 \\
\hline \multicolumn{6}{|c|}{ Competitive services } \\
\hline Non-hazardous waste collection & 791 & 795 & 729 & 4 & -66 \\
\hline Rewarded or contract-based property management & 684 & 701 & 618 & 17 & -83 \\
\hline Complex objects' maintenance & 1,409 & 1,547 & 1,525 & 138 & -22 \\
\hline Other types of cleaning activity & 534 & 535 & 484 & 1 & -51 \\
\hline Total in Ukraine & 6,021 & 6,344 & 6,159 & 323 & -185 \\
\hline \multicolumn{6}{|c|}{ Poltava region } \\
\hline \multicolumn{6}{|c|}{ Monopolized services } \\
\hline Electricity distribution & 3 & 5 & 5 & 2 & 0 \\
\hline Gas production & $\mathrm{x}$ & 1 & 2 & $\mathrm{X}$ & 1 \\
\hline Distribution of gaseous fuels through local pipelines & 2 & 2 & 4 & 0 & 2 \\
\hline Sale of gas through local pipelines & 7 & 7 & 5 & 0 & -2 \\
\hline Supply of steam, hot water and conditioned air & 14 & 18 & 17 & 4 & -1 \\
\hline Water sampling, cleaning and supply & 65 & 65 & 77 & 0 & 12 \\
\hline \multicolumn{6}{|c|}{ Competitive services } \\
\hline Non-hazardous waste collection & 28 & 29 & 23 & 1 & -6 \\
\hline Rewarded or contract-based property management & 10 & 11 & 11 & 1 & 0 \\
\hline Complex objects' maintenance & 42 & 40 & 40 & -2 & 0 \\
\hline Other types of cleaning activity & 19 & 19 & 19 & 0 & 0 \\
\hline
\end{tabular}

Source: Based on the State Statistics Service (2017) data.

Notwithstanding that the equilibrium price of the services at the housing and utility services market is being established, as at other markets, by the proportion of demand and supply for the services, but, as Apostoliuk aptly notes, implementation of market mechanisms is possible not in all the segments of this market, as this market includes the sectors, which belong to natural monopoly (Apostoliuk, 2014).

According to the existing natural monopoly, there are specific rules for housing and utility services enterprises operation, tariffs formation, crosssubsidization and enterprises subsidization. But the long-term absence of the economic stimuli connected with the natural monopolization of this sphere had negative consequences for the state of Ukrainian housing and utility services sector. As known, competition is the main engine of innovative processes, it forces the enterprises to constantly update and improve in order to have demand at the market. Accordingly, inadequate system of tariffs formation, which lies in covering the part of expenses on services production at the expense of the money of executive power and local selfgovernment bodies, and large amount of privileged categories of consumers and big debt for payment of 
the cost of received housing and utility services limits stimulation of competition in the sphere.

Hypothesis 2: Ensuring long-term activities and continuity of production is a key need of housing and utility services enterprises.

As services provided by housing and utility enterprises are vitally important for humans, this creates the need to provide its continuous operation. Taking into account comprehensive nature of providing the services and trends toward increase in the number of consumers (Table 2), the aim of housing and utility services enterprises management is to ensure the conditions for maintaining their life activity.

Table 2. Increase in the number of consumers of housing and utility services in the period 2014-2016

\begin{tabular}{|c|c|c|c|c|c|}
\hline \multirow{2}{*}{ Number of consumers according to the types of services* } & \multirow{2}{*}{2014} & \multirow{2}{*}{2015} & \multirow{2}{*}{2016} & \multicolumn{2}{|c|}{ Change $(+;-)$} \\
\hline & & & & In 2015 compared to 2014 & In 2016 compared to 2015 \\
\hline \multicolumn{6}{|c|}{ Ukraine } \\
\hline Gas supply & $13,454,416$ & $12,398,953$ & $12,447,074$ & $-1,055,463$ & 48,121 \\
\hline Central heating and hot water supply & $7,163,481$ & $6,039,895$ & $5,973,904$ & $-1,123,586$ & $-65,991$ \\
\hline Water supply and water discharge & $12,258,304$ & $11,103,636$ & $10,971,198$ & $-1,154,668$ & $-132,438$ \\
\hline Maintenance of houses and buildings and adjacent territories & $8,606,342$ & $7,649,178$ & $8,465,973$ & $-957,164$ & 816,795 \\
\hline Waste disposal & $6,314,280$ & $5,249,947$ & $5,445,332$ & $-1,064,333$ & 195,385 \\
\hline Total in Ukraine & $47,796,823$ & $42,441,609$ & $43,303,481$ & $-5,355,214$ & 861,872 \\
\hline \multicolumn{6}{|c|}{ Poltava region } \\
\hline Gas supply & 604,241 & 604,241 & 604,241 & 0 & 0 \\
\hline Central heating and hot water supply & 214,874 & 214,874 & 214,874 & 0 & 0 \\
\hline Water supply and water discharge & 406,933 & 406,933 & 406,933 & 0 & 0 \\
\hline Maintenance of houses and buildings and adjacent territories & 287,664 & 287,664 & 287,664 & 0 & 0 \\
\hline Waste disposal & 186,187 & 186,187 & 186,187 & 0 & 0 \\
\hline Total in Poltava region & $1,699,899$ & $1,699,899$ & $1,699,899$ & 0 & 0 \\
\hline
\end{tabular}

Note: *According to the number of personal accounts.

Source: Based on the State Statistics Service (2017) data.

But the technical conditions of the main means, degree of wear and tear at the majority of enterprises achieved the maximum allowable level and endangered not only long-term perspective of the activity, but also ensuring the continuous production in the short term. So the percent of old and damaged water supply networks in 2016 was extremely high: in Lviv region $-50.1 \%$ (of total length of networks), Dnipropetrovsk region $-47.5 \%$, Kirovohrad region $-45.6 \%$, Kharkiv region $-44.2 \%$, Kherson region $-40.8 \%$ and in Kyiv $-42.5 \%$; in other regions, this indicator was less than $40 \%$; in Donetsk and Luhansk regions, it was $72.3 \%$ and $53.7 \%$, respectively (Національна доповідь [Natsionalna dopovid], 2016).

Residential fund also has the significant amount of "old" and damaged residential premises (Table 3), which creates additional maintenance burden for housing and utility services enterprises.

Table 3. Indicators of the state of old and damaged residential premises in Ukraine and its regions in 2016

\begin{tabular}{|c|c|c|c|c|c|c|}
\hline \multirow[b]{2}{*}{ Region } & \multicolumn{3}{|c|}{ Old residential fund of Ukraine } & \multicolumn{3}{|c|}{ Damaged residential fund of Ukraine } \\
\hline & 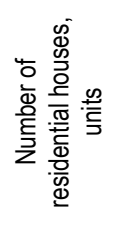 & 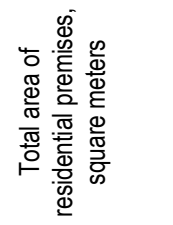 & 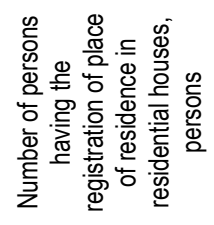 & 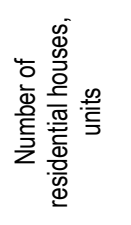 & 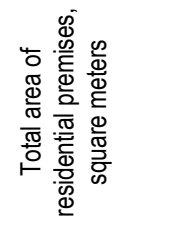 & 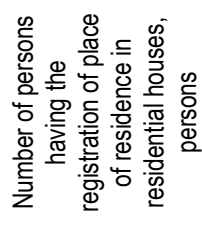 \\
\hline Ukraine & 45207 & 3303439 & 68689 & 16473 & 1029579 & 18301 \\
\hline Vinnytsia & 4288 & 220894 & 2040 & 1453 & 79044 & 163 \\
\hline Volyn & 981 & 62652 & 938 & 175 & 8498 & 20 \\
\hline Dnipropetrovsk & 1977 & 331581 & 11149 & 861 & 73655 & 1260 \\
\hline Donestk & 3198 & 235514 & 5239 & 1555 & 96634 & 1503 \\
\hline Zhytomyr & 3174 & 226455 & 4317 & 800 & 52700 & 648 \\
\hline Zakarpattia & 391 & 30098 & 872 & 97 & 5510 & 151 \\
\hline Zaporizhzhia & 577 & 88085 & 4293 & 370 & 26659 & 467 \\
\hline Ivano-Frankivsk & 1031 & 50296 & 1054 & 415 & 23899 & 711 \\
\hline Kyiv & 2774 & 124249 & 2003 & 799 & 42691 & 1188 \\
\hline Kirovohrad & 95 & 15619 & 793 & 4 & 5178 & 61 \\
\hline Luhansk & 411 & 48964 & 1830 & 136 & 13597 & 218 \\
\hline
\end{tabular}


Table 3. (cont.) Indicators of the state of old and damaged residential premises in Ukraine and its regions in 2016

\begin{tabular}{|c|c|c|c|c|c|c|}
\hline \multirow[b]{2}{*}{ Region } & \multicolumn{3}{|c|}{ Old residential fund of Ukraine } & \multicolumn{3}{|c|}{ Damaged residential fund of Ukraine } \\
\hline & 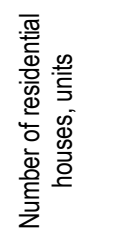 & 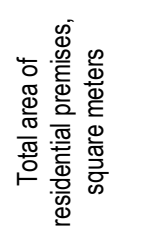 & 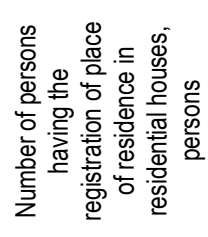 & 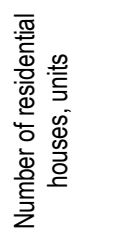 & 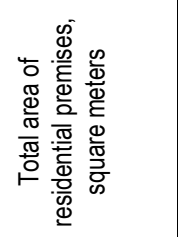 & 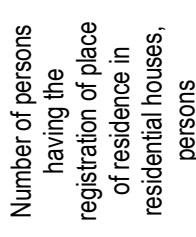 \\
\hline Lviv & 1101 & 89090 & 4284 & 494 & 41374 & 1249 \\
\hline Mykolaiv & 473 & 43324 & 1098 & 189 & 17165 & 208 \\
\hline Odesa & 4633 & 355363 & 12198 & 2266 & 174136 & 5282 \\
\hline Poltava & 2756 & 175459 & 3739 & 1180 & 52433 & 119 \\
\hline Rivne & 1703 & 88331 & 1331 & 459 & 19815 & 186 \\
\hline Sumy & 3264 & 148322 & 783 & 775 & 31889 & 134 \\
\hline Ternopil & 927 & 42234 & 517 & 748 & 34669 & 209 \\
\hline Kharkiv & 3913 & 513711 & 4703 & 762 & 48557 & 1510 \\
\hline Kherson & 888 & 43533 & 775 & 457 & 26148 & 254 \\
\hline Khmelnytskyi & 1838 & 92321 & 695 & 475 & 22973 & 102 \\
\hline Cherkasy & 3218 & 159716 & 1219 & 1171 & 65797 & 626 \\
\hline Chernivtsi & 194 & 15017 & 827 & 437 & 32338 & 1384 \\
\hline Chernihiv & 1208 & 61434 & 870 & 372 & 19954 & 154 \\
\hline Kyiv (city) & 194 & 41177 & 1122 & 23 & 14266 & 494 \\
\hline
\end{tabular}

Source: Based on the State Statistics Service (2017) data.

High degree of wear and tear of the main means carries a risk for ensuring entrepreneurial activity and creates a need for renewing the main resources as a necessary condition for continuing the activity.

Hypothesis 3: Quality, nomenclature of services, their reliability, economic feasibility of the tariffs, social and environmental labor security do not comply with the requirements of European standards for country's development.

European Charter of Local Self-Government states that the executive bodies and local self-government bodies can establish the tariffs at the level lower than the economically sound provided the recovery of the difference from the budgets of the corresponding levels (Charter, 1985). It is done to ensure the massive use of housing and utility services and ensure the social security of the separate population strata. As Rovenchak notes, economically sound tariffs are the objective level of equilibrium price of demand and supply (Rovenchak, 2013). Kotsiurba defines as minimum possible payment, which is a financial basis for current production of housing and utility services, which comply with the approved quality standards taking into account the necessary expenses for extended reproduction of the main funds (Kotsiurba, 2012). But today the technical conditions of housing and utility services enterprises are poor and cause the need for infusion of money. As Brazhnikova fairly notes, now there are observed decreased reliability, sustainability and safety of engineering pathways operation, the majority of housing and utility services enterprises are in emergency mode (Brazhnikova, 2010). That's why the trend towards increase in tariff rate is necessary, but runaway growth rates require the facts of validity proof.

The mentioned hypothesis is confirmed by the thoughts of scientists concerning invalidity of tariffs and service quality, non-compliance of "the tariffs with actual cost of housing and utility services, which gives rise to cross-subsidization" (Kotsiurba, 2012); "staffing with the needs of housing and utility services complex when passing to new management conditions"; "quality of services with their cost, not fully provided housing and utility services" (Poliakova, 2012); "imperfect tariff policy (the tariffs do not fully reimburse the expenses for services production)" (Lukianov, 2014).

Apart from problems with production capabilities, the absence of human resources is one more issue to be solved. The problem can be defined in that people of working age do not want to work in the housing and utility services sector because of low wages, absence of motivation and lack of prestige for this work. That's why the number of workers in this area constantly decreases, this leads to incapability of the housing and utility services enterprises to fully serve the needs of consumers.

Hypothesis 4: Presence of the significant accounts receivable, which is caused by the time lag between the consumers' use of services and resources provided and payment for them.

As the main specific feature of housing and utility services enterprises is the time lag between providing the service and paying for it, this caused the range of problems, which are reflected in the 
financial state of the enterprises. So Haidenko studied the influence of the indicators on the level of population's payment for housing and utility services, as a result of which it was defined that the indicator of the population's debt for housing and utility services has the greatest influence on level of population's payment for housing and utility services (Haidenko, 2017).

The analysis of the statistical data only confirms the significant amounts of accounts receivable for all types of monopolistic housing and utility services (Table 5).

Table 4. Growth of population's debt for housing and utility services in the period 2014-2016

\begin{tabular}{|c|c|c|c|c|c|c|c|c|}
\hline \multirow[b]{2}{*}{ Regions } & \multicolumn{3}{|c|}{ Total sum of debt, million UAH } & \multicolumn{2}{|c|}{$\begin{array}{l}\text { Level of the population's payment from the } \\
\text { beginning of the year, } \%\end{array}$} & \multicolumn{3}{|c|}{$\begin{array}{c}\text { Group according to the level } \\
\text { of payment }\end{array}$} \\
\hline & 事 & 它o & 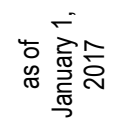 & 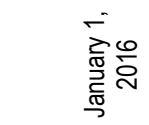 & 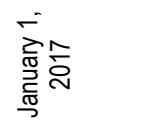 & בق & $\frac{\frac{0}{\bar{O}}}{\frac{0}{2}}$ & ․ㅗㅍ \\
\hline Vinnytsia & 96.3 & 84.5 & 110 & 118.8 & 98.1 & & 1 & \\
\hline Volyn & 75.1 & 76.3 & 43.2 & 92.1 & 104 & & & 1 \\
\hline Dnipropetrovsk & 1948.4 & 2186.5 & 2644.6 & 94.3 & 85.5 & 1 & & \\
\hline Donetsk & 904.8 & 1133.4 & 1286.8 & 85.9 & 85.1 & 1 & & \\
\hline Zhytomyr & 137.5 & 145.9 & 178.7 & 114.3 & 95.1 & & 1 & \\
\hline Zakarpattia & 121.2 & 128.3 & 123.2 & 87.1 & 95.2 & & 1 & \\
\hline Zaporizhzhia & 642.9 & 725.2 & 868.1 & 89.5 & 91.4 & 1 & & \\
\hline Ivano-Frankivsk & 108.4 & 115.4 & 119.3 & 81.1 & 98.6 & & 1 & \\
\hline Kyiv & 345.5 & 369.6 & 451.2 & 98.7 & 94.3 & & 1 & \\
\hline Kirovohrad & 122.5 & 119.9 & 110.4 & 113 & 102.2 & & 1 & \\
\hline Luhansk & 268.7 & 345 & 403.6 & 85.2 & 84.4 & 1 & & \\
\hline Lviv & 366.3 & 269 & 261.1 & 95.6 & 99.7 & & 1 & \\
\hline Mykolaiv & 197.6 & 202 & 260.9 & 106.4 & 92.9 & 1 & & \\
\hline Odesa & 563.6 & 603 & 831.7 & 92.5 & 90.8 & 1 & & \\
\hline Poltava & 275.1 & 283.1 & 385.8 & 93.3 & 91.9 & 1 & & \\
\hline Rivne & 144.1 & 152.1 & 74.8 & 111.6 & 113.6 & & & 1 \\
\hline Sumy & 207.4 & 169.3 & 154.2 & 85.7 & 106.3 & & & 1 \\
\hline Ternopil & 61.7 & 62.7 & 76.7 & 68.8 & 94.7 & & 1 & \\
\hline Kharkiv & 1368.7 & 1427.7 & 1737.8 & 92 & 95.6 & & 1 & \\
\hline Kherson & 186.1 & 218.5 & 250.4 & 97.5 & 94.4 & & 1 & \\
\hline Khmelnytskyi & 94.9 & 81.5 & 73.4 & 104.5 & 99.8 & & 1 & \\
\hline Cherkasy & 199.7 & 212.3 & 234.5 & 119 & 97.6 & & 1 & \\
\hline Chernivtsi & 45.4 & 45.6 & 77.5 & 88.4 & 87.5 & 1 & & \\
\hline Chernihiv & 113 & 88.8 & 70.1 & 112.2 & 104.1 & & & 1 \\
\hline Total & 10137.8 & 10977.6 & 13735.4 & $x$ & $x$ & 8 & 12 & 4 \\
\hline
\end{tabular}

Source: Based on the State Statistics Service (2017) data.

Herewith, grouping the regions of Ukraine according to the level of population's payment for the services showed that the majority of the regions have the middle level (12 regions), but there is a sufficient number of regions with low level of payment (8 regions).

Hypothesis 5: Dependence of results of enterprises financial activity on the current political and economic situation in the country.

Political and economic vectors of development, established by government, have direct influence on the financial state of housing and utility services enterprises, in particular, on the important elements such as business activity, investment climate, profitability and competitiveness of the activity. State financial policy for a corresponding year establishes the priorities for support in the areas of economic activity and defines the measures for stimulating or inhibiting the development of the corresponding areas of economic activity. Besides, the political and economic situational conditions which have evolved in the corresponding period in the state also have the significant influence on the financial state of housing and utility services enterprises. Besides, as Poliakova aptly notes, the financial state of housing and utility services enterprises is affected by a range of factors divided into four groups: political, economic, socio-cultural and technological. Accordingly, the author defined that the political factors having an influence on housing and utility services sector include: imperfect modern legislation, which regulates the activity of this sector of economy; lack of due implementation of the developed industry reforms program; lack of the sole continuous authority able to 
implement the directions of industry reforms; lack of financing from the state; repeated changes in the legislative basis as a result of elections at all the levels of government; absence of municipal support of enterprises development (Poliakova, 2012).
The study of the correlation between the index of political stability of Ukraine and final financial result of housing and utility enterprises activity (Figure 1) shows the close interdependence (correlation coefficient is 0.857 ) and common trends towards changes.

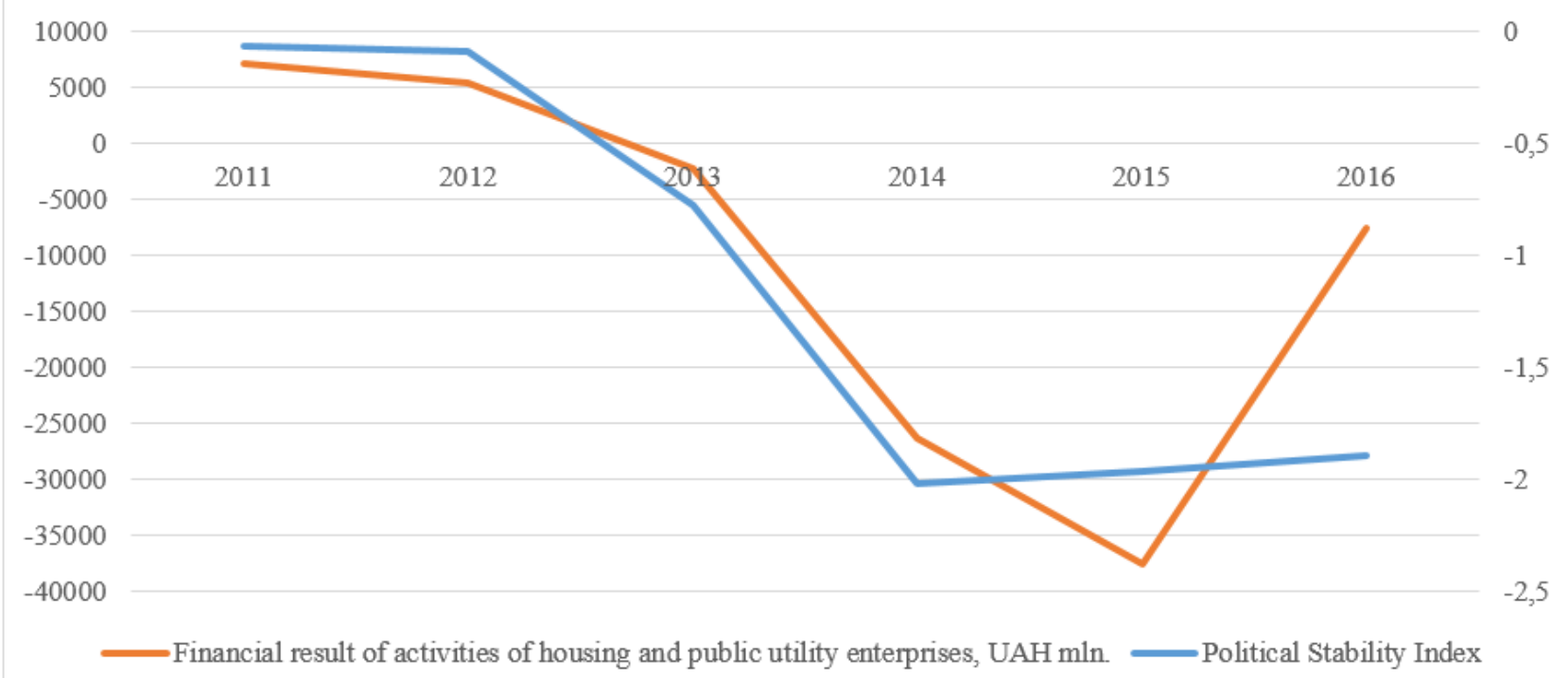

Source: Based on the State Statistics Service (2017) data and The Global Economy (2017).

Figure 2. Growth of the index of political stability of Ukraine and financial result of housing and utility enterprises activity in the period 2011-2016

As for the economic situation, the authors define the following factors: constantly increasing level of inflation; unfavorable investment climate in the industry (Poliakova, 2012); low solvency of the population; poor competition (Kotsiurba, 2012); level of population's income and level of differentiation of the population according to income (Apostoliuk, 2014). The study of the interrelationship between the results of the activity and economic situation in the country performed based on the analysis of the correlation between the index of economic development of Ukraine and financial results of housing and utility services enterprises activity (Figure 2) showed the close interrelationship (correlation coefficient is 0.9313) and identical vectors of changes.

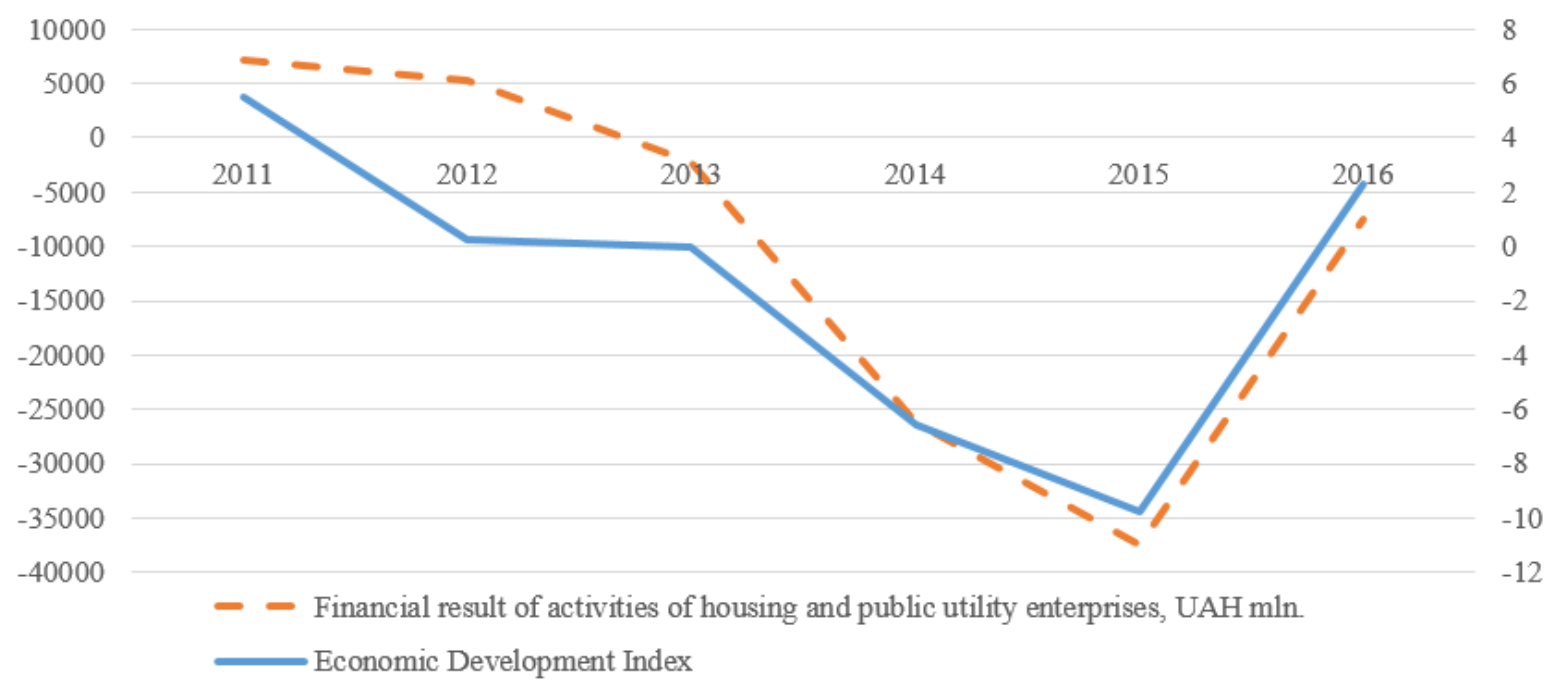

Source: Based on the State Statistics Service (2017) data and The Global Economy (2017).

Figure 3. Growth of the index of economic development of Ukraine and financial result of housing and utility enterprises activity in the period 2011-2016 
Flexibility of economic and political environment and its significant influence on housing and utility services enterprises activity, which is confirmed by calculations, leads to the conclusion about the need for increasing the level of situational management of the activity.

Hypothesis 6: Limitations of enterprise management functions in the sphere of setting up prices and standards for services.

A defining feature of housing and utility services enterprises activity is state regulation of pricing for separate types of housing and utility services. As Kotsiurba aptly notes, state intervention, along with other factors (sum of expenses (cost of services); competition; solvency of the population) is key in the formation of tariffs of housing and utility services enterprises (Kotsiurba, 2012). Herewith state intervention is based on establishing the norms and tariffs, taxation and targeted financing. According to the Law of Ukraine "On Prices and Pricing", state regulated prices are established for goods, which have a significant influence on general level and growth of prices, have substantial social significance, and for goods, which are produced by the entities occupying the monopolistic (dominating) position at the market (Law of Ukraine, 2012). Herewith the state tariff policy in establishing prices for housing and utility services is aimed at improving the social conditions of the population at the expense of economic and social feasibility and differentiation according to the quality of life in the different regions.

Taxation as another factor of state regulation of housing and utility services enterprises activity, on the one hand, can be the instrument for stimulating the enterprises by decreasing the expenses when producing the services, and on the other hand, worsens the final financial result of the activity.

Along with this, support from the government and the responsible organization that must manage the housing and utility services sector does not work properly. One should agree that, on the one hand, state as a main regulator of the process of competitive environment formation at the housing and utility services market and subject of anti-monopoly policy covers to the largest extent the housing and utility services sector with its regulatory activity, herewith actually doing nothing for real reforms of this economy (Kotsiurba, 2012).

Proving the described hypotheses is the basis for defining, along with general functions of enterprises management, a range of functions specific for housing and utility services enterprises, in particular: balancing the conditions for housing and utility services monopolistic markets activity; creating the conditions for continuous activity of housing and utility services enterprises; improving the quality and nomenclature of services, their reliability, economic feasibility of the tariffs, social and environmental labor security; minimizing the accounts receivable; increasing the control of the influence of the factors of economic and political environment on housing and utility services enterprises activity; regulating the prices and norms for housing and utility services.

\section{Conclusion}

Given significant problems in housing and utility services enterprises activity, confirmed by the hypotheses proved above, vector indicators of the development of housing and utility services enterprises potential were defined, which are based on solving these problems. In particular, increasing the level of provision of the population with housing and utility services in the necessary amount, of high quality and for reasonable prices, ensuring the effective tariff policy; creating the conditions for development, renewal and effective operation of all housing and utility services enterprises, enterprises and organizations of different forms of ownership; deepening the demonopolization of housing and utility services sector; ensuring the decent competition and possibility for home owners to choose the service provider on residential houses maintenance and affect the quality of its maintenance; minimizing the use of resources, development of programs of heat, water and energy conservation. Future directions of the study are aimed at using the foreign experience of managing the housing and utility services enterprises potential in the domestic practice.

\section{References}

1. Apostoliuk, A. (2014). Реалії та перспективи розвитку конкурентного середовища на ринку житловокомунальних послуг [Realii ta perspektyvy rozvytku konkurentnoho seredovyscha na rynku zhytlovokomunalnykh posluh]. Halytskyi ekonomichnyi visnyk, 46(3), 53-60.

2. Baldzhy, M. D. (2017). Шляхи удосконалення розвитку житлово-господарського комплексу (на прикладі міста Одеси) [Shliakhy udoskonalennia rozvytku zhytlovo-hospodarskoho kompleksu (na prykladi mista Odesy)]. Naukovyi visnyk Odeskoho natsionalnoho ekonomichnoho universytetu, 1-2(243-244), 5-16.

3. Brazhnikova, L. N. (2010). Стратегическое управление финансовой деятельностью предприятий ЖКХ [Strategicheskoe upravlenie finansovoy deyatelnostyu predpriyatiy ZHKKH] (499 p.). Donetsk: Yuho-Vostok. 
4. Dymchenko, O. V. (2009). Житлово-комунальне господарство в реформаційному процесі: аналіз, проектування, управління [Zhytlovo-komunalne hospodarstvo v reformatsiinomи protsesi: analiz, proektuvannia, upravlinnia] (356 p.). Kharkiv: KHNAMH.

5. Haidenko, S. M. (2017). Економетричне моделювання показників функціонування підприємств житловокомунального господарства [Ekonometrychne modeliuvannia pokaznykiv funktsionuvannia pidpryiemstv zhytlovokomunalnoho hospodarstva]. Ekonomichnyi visnyk Zaporizkoi derzhavnoi inzhenernoi akademii, 2-1(08), 91-97.

6. Kotsiurba, O. Yu. (2012). Особливості тарифної політики у житлово-комунальній cфepi [Osoblyvosti taryfnoi polityky u zhytlovo-komunalnii sferi]. Naukovi pratsi Kirovohradskoho natsionalnoho tekhnichnoho universytetu, 22(1), 244-248.

7. Lukianov, V. I. (2014). Стратегічні напрями розвитку житлово-комунального господарства регіону [Stratehichni napriamy rozvytku zhytlovo-komunalnoho hospodarstva]. Ekonomika ta upravlinnia pidpryiemstvamy mashynobudivnoi haluzi: problemy teorii ta praktyky, 5(29), 99-110.

8. Palme, U. (2010). Multiple conceptions of sustainable urban water systems: problem or asset. Water Policy, 12(3), 425-443.

9. Peresada, K. О. (2007). Інноваційна діяльність як засіб реформування житлово-комунального господарства [Innovatsiina diialnist yak zasib formuvannia zhytlovo-komunalnoho hospodarstva]. Retrieved from ena.lp.edu.ua/bitstream/ntb/34078/1/45_205-211.pdf (accessed on March 21, 2018).

10. Poliakova, N. (2012). Житлово-комунальне господарство: сучасні перспективи розвитку [Zhytlovokomunalne hospodarstvo: suchasni perspektyvy rozvytku]. Ekonomichnyi analiz, 11(3), 350-353.

11. Robinson, J. \& Cole, R. J. (2015). Theoretical underpinnings of regenerative sustainability. Build. Res. Inform., 43(2), 133-143.

12. Rovenchak, Т. Н. (2013). Тарифна політика - один з напрямів реформування галузі ЖКГ [Taryfna polityka odyn z napriamiv reformuvannia haluzi ZHKKH]. Naukovo-tekhnichnyi zbirnyk Suchasni tekhnolohii, materialy $i$ konstruktsii v budivnytsvi, 1(25), 119-124.

13. State Statistics Service of Ukraine (n.d.). Retrieved from www.ukrstat.gov.ua// (accessed on March 27, 2018).

14. Takala Annina (2017). Understanding sustainable development in Finnish water supply and sanitation services. International Journal of Sustainable Built Environment, 6, 501-512.

15. The Global Economy: Economic indicators for over 200 countries. Retrieved from: https://www.theglobaleconomy.com

16. Міністерство регіонального розвитку, будівництва та житлово-комунального господарства України [Ministerstvo rehionalnoho rozvytklu, budivnytsva ta zhytlovo-komunalnoho hospodarstva Ukrainy] (n.d.). Національна доповідь про якість питної води та стан питного водопостачання в Украӥні у 2016 роц̧і [Natsionalna dopovid pro yakist pytnoi vody ta stan pytnoho vodopostachannia v Ukraini $v 2016$ rotsi]. Retrieved from http://www.minregion.gov.ua/wp-content/uploads/2017/12/Proekt-Nats.-dop.-za-2016-rik.pdf (accessed on March 23, 2018).

17. Про житлово-комунальні послуги: Закон України № 2189-19 від 09.11.2017 [Pro zhytlovo-komunalni posluhy: Zakon Ukrainy No. 2189-19 vid 09.11.2017]. Retrieved from http://zakon3.rada.gov.ua/laws/show/218919 (accessed on March 5, 2018).

18. Про природні монополії: Закон України від 20.04.2000 року № 1682-III станом на 11.06.2017 [Pro pryrodni monopolii: Zakon Ukrainy vid 20.04.2000 roku No. 1682-III stanom na 11.06.2017]. Retrieved from http://zakon0.rada.gov.ua/laws/show/1682-14 (accessed on March 21, 2018).

19. Про ціни та ціноутворення: Закон України від 21.06.2012 року № 5007-VI станом на 30/01/2018 [Pro tsiny ta tsinoutvorennia: Zakon Ukrainy vid 21.06.2012 roku No. 5007-VI stanom na 30/01/2018]. Retrieved from http://zakon2.rada.gov.ua/laws/show/5007-17 (accessed on March 21, 2018).

20. Рада Свропи (Rada Yevropy) (n.d.). Свропейська Хартія місиевого самоврядування [Yevropeiska Khartiia mistsevoho samovriaduvannia]. Retrieved from http://zakon1.rada.gov.ua/laws/show/994_036 